\title{
WETLAND CAPABILITIES IN ENHANCING WETLAND TOURISM IN GANDOMAN, IRAN
}

\author{
M. KHOSHKAM ${ }^{1}$, A. MARZUKI ${ }^{1} \&$ Z. ARZJANI ${ }^{2}$ \\ ${ }^{1}$ School of Housing, Building \& Planning, Universiti Sains Malaysia, Pulau Pinang, Malaysia. \\ ${ }^{2}$ Faculty of Geography, Islamic Azad University of Central Tehran Branch, Iran.
}

\begin{abstract}
The uniqueness of wetland tourism has become a significant component in the tourism industry, particularly in developing countries. Without any doubt, wetland areas have a lot of capabilities to attract tourists. Nevertheless, the relationship between local communities and capabilities of wetland areas continues to be an obstacle that hampers the successful use of the natural resources. A key component of this relationship is the lack of local communities' training regarding wetland areas and their limited knowledge on how to use these resources. Thus, this study reviews the theoretical and empirical issues of the relationship between local communities and their possible contribution in wetland tourism management based on a case study done in the Gandoman wetland area located in the Chahar-Mahal and Bakhtiari province of Iran. This study aims to make use of measurements derived from field study methods and descriptive method which was conducted at the Gandoman area that involved a series of semi-structured interviews to determine the strengths, weaknesses, opportunities and threats via the SWOT strategies/analysis. Results presented here support those derived from previous studies about the training of local communities in using wetland potential and the relationship with environmental friendly behaviour. Managers and planners in various relevant organizations must work together in developing well thought strategic agenda to benefit from wetland tourism. The authors then subsequently provide some strategies and offer suggestions on ways to develop wetland tourism within the Gandoman wetlands.

Keywords: Gandoman, SWOT analysis, tourism activities, wetland, wise use.
\end{abstract}

\section{INTRODUCTION}

In recent decades, the study of the tourism industry has gained interest in search for the extraordinary in comparison with an individual's daily life and environment [1]. In contrast with the other branches of the tourism industry, ecotourism and nature-based tourism activities respond to people who desire to travel with different aims such as escaping to nature, relaxation, discovery, learning and others features of daily life [2]. As mentioned in a variety of literature, the tourism industry has encouraged conservation as it contributes to the national economy [3]. While many studies have been conducted within developed countries with regard to the tourism industry, few have been carried out from the perspective of developing countries and the third world. The value of wetland areas as well as the different associated services and structures for the local communities who are living in the surrounding regions needs to be not only studied but validated as well [4]. One of the most notable developing countries is Iran with an area of 1,648,195 $\mathrm{km}^{2}$. Located in the Middle East and surrounded by the Caspian Sea, Persian Gulf and Oman Sea, Iran has many unique natural resources.

As a country, Iran demonstrates a great diversity of geomorphological aspects. These geomorphological differences have been identified as one of the major factors of the rich and unique biodiversity found in this country. One of the main components of the rich biodiversity in Iran is its wetlands. Previous studies have shown there are many wetland areas with a large number of local communities/tourist activities within the vicinity of these wetlands areas. These activities include fishing, boating and skiing, and therefore, in order to sustain these activities, these natural environments need to be protected for future generations, not only from within Iran but also from throughout the world [5]. Wetlands play a key role in human life as unique environments with unique water life 
(fauna and flora). These ecosystem areas are divided into two types: Natural and Constructed. 'Natural' wetland areas are in geographical areas where water covers soil. 'Constructed' wetlands are similar but the ecosystem resources and their foundation are a combination of biological and chemical processes [6].

Iran has a number of natural wetland areas; one of which is located in the Chahar-Mahal and Bakhtiari province within the district of Gandoman with a latitude of $49^{\circ}-31^{\prime}$ to $53^{\circ}-31^{\prime} \mathrm{N}$ and a longitude of $5^{\circ}-51^{\prime}$ to $7^{\circ}-51^{\prime} \mathrm{E}$ and is called the Gandoman wetlands [7]. These wetlands have a unique set of problems. Some of these problems include pollution, draining, unsustainable development and a lack of planning for wetlands tourism. Sustainability of wetland areas is a major strategy for nature conservation in any city and the discussion for the wise use of wetlands must include new approaches for sustainability based on each activity taking place there [8]. Natural resources create economic benefits and nature conservation is the key element which contributes to the quality of life for the local community [2].

Therefore, preserving the balance of the fundamental and biological conditions of the wetlands is needed. Understanding the ecosystem depends on its individual parts, as well as the ability to change or remove each of these parts. Thus, local communities need to have the perception and preparation for sustainable development in wetlands tourism which can subsequently help planners and decision makers recognize the real concerns within these areas and initiate policies and action that can minimize trouble and optimize benefits [9]. This present study aims to contribute in filling the gap that exists in the literature on this area of study. More precisely, the objective of this study is to describe the present condition of the Gandoman wetlands and its capabilities as a natural resource located in the south-west of the Chahar-Mahal and Bakhtiari province, as well as its potential for wetland tourism development.

\section{BASIC CONCEPTS TOWARDS WETLAND DEFINITION}

A considerable amount of literature has been published on the wise use of wetland areas. What is known about the wise use of the wetlands is largely based upon empirical studies that investigate how policy makers and planners determine major policy decisions, and how the wetlands are used in the present and future. The concept of 'Wise Use' of wetlands, laid out in the intergovernmental Ramsar Convention on wetland areas, signed by 153 parties $^{1}$, recognizes the need to incorporate development and conservation. One of the alternatives of human development on wetland ecosystems is necessities alteration. Thus, the concept of the 'Wise Use' advocates that before any changes are made, the processes that sustain the ecosystems need to be closely examined [10]. The Ramsar Convention $^{2}$ on wetlands of international importance aims to stop the worldwide loss of wetlands and overcome poor management. Recreational activities that can be done in wetland areas such as fishing, canoeing and boating are all based on the activities in natural environments and they constitute the interesting features for wetlands, embodied under the term 'ecotourism' [11].

The resource-based view has received considerable attention during the past two decades for strategic management in these areas with regard to natural resources and their capabilities within tourism [12-15]. There are three resource-based constructs, namely resources, competencies, and capabilities. This study will apply the concept of capability within the context of tourism development particularly in wetland capability. Based on [16] and [17], destination capabilities have the collective ability to integrate; gain, reconfigure, and release distributed resources and competencies, and effectuate change. According to these statements, the way of applying the concept of capabilities in

\footnotetext{
${ }^{1}$ http://www.ramsar.org

${ }^{2}$ The Convention on Wetlands (Ramsar, Iran, 1971) which is more commonly known thereafter as the 'Ramsar Convention'
} 
tourism destinations are through two distinct capabilities which are 1) destination image and branding [18, 19] and 2) utilization of distributed resources and competencies [20, 21, cited in 22]. Basically, wetlands provide many vital services to the human society, but at the same time they are very fragile adaptive systems and are ecologically sensitive. These help to explain the relevant processes and problems which are indicative of the strategies within both natural and social sciences that contribute to an increased understanding in this matter [23]. In these areas, there are two different perspectives for tourism with regard to the importance of implementing appropriate protection measures and substantial environmental impacts [24].

The first definition of the wetland was issued by the Ramsar Convention, Iran, in 1971, whereby the wetlands are '... areas of marsh, fen, peatland or water, whether natural or artificial, permanent or temporary, with water that is static or flowing, fresh, brackish, or salt, including areas of marine waters, the depth of which at low tide does not exceed six meters.' Wetlands also include '.... riparian and coastal zones adjacent to wetlands, or islands or bodies of marine water deeper than six meters at low tide lying within' [25].

\subsection{Local communities' awareness on the wise use of wetlands capabilities}

As mentioned earlier, developing countries have lack of information on the ecological and biodiversity circumstances, particularly in wetlands [10]. In different organizations all over the world, one of the aspects considered is training residents within local communities on the importance of the wetlands to tourism. This rule is a fundamental component in protected areas, particularly in the wetland areas. Evidence has shown environmental tourism is directly linked with the local communities who are living in the vicinity of the wetland areas [26]. In the study area of this research, lack of information in local communities regarding the wise use of the wetland areas has been revealed.

To clarify this statement, a framework of the awareness of the local communities on the wise use of wetlands is prepared (Fig. 1) with three dimensions that can complete the relationship between local communities and the wise use of the wetlands. These dimensions include 'awareness as described previously by the residents' training and knowledge in the local community'. The second part is 'wise use with increasing responsibility and support of the wetlands'. The third part, 'environmentally friendly', includes different aspects such as reducing the conflict and exploitation between local communities/tourists and the wetlands, ensuring the wise use of the wetlands, interacting in a friendly manner with the wetlands, realizing their potential benefits, and promoting tourism development and exercising the wise use and 'sustaining utilization' concerning the wise use of the wetlands.

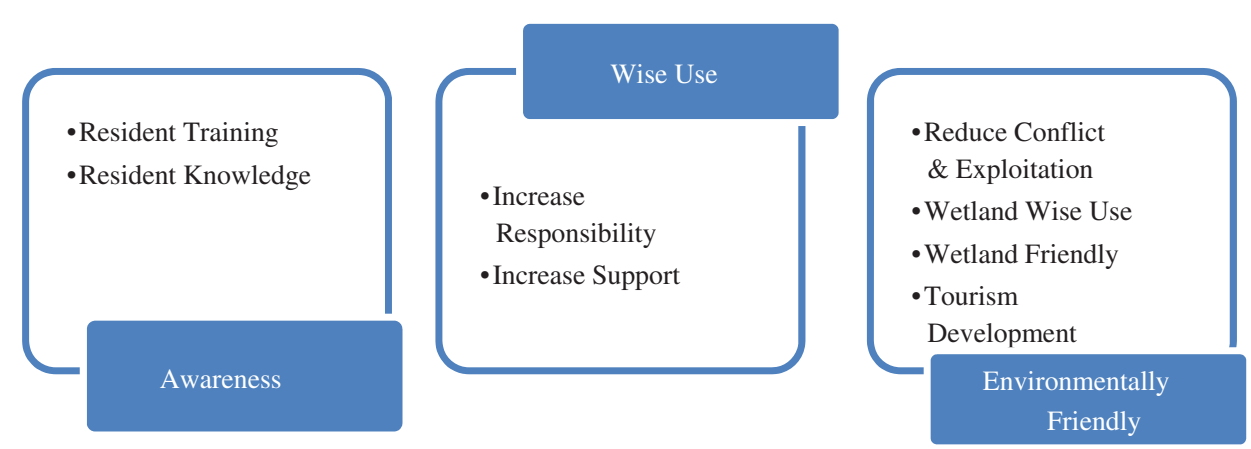

Figure 1: The different dimensions of the wise use of the wetlands. Source: [27]. 
Each year on World Environment Day, visitor centres are focused on ensuring the stability, sustainability and also the accessibility of the wetlands' ecosystems. Therefore, in the local community, the sustainability of the wetland management has received most thought from their role and participation as well as sustaining the value of the wetlands by effective utilization and management through the sound knowledge and cooperation between local people and their communities in surrounding wetland areas [28]. Thus, according to previous literature, questions that emerge surrounding wetland development are "What is it that stakeholders wish to gain or achieve from the wetland? What will be the state of the wetland when their objectives are met? Who will benefit from the growth of the wetlands, and in what way will they benefit from the wetlands?' Therefore, to a certain extent, depending on the uniqueness and roles of the wetland development, there are many ways in which these questions are significant at local, national and international levels [10].

It is clear that the local communities of the Gandoman wetlands are willing to work hard for the wetland. They have been supporting all the plans outlined by the Department of Environment and other concerned organizations (Field Study, 2008). In recent years, there has been an increasing amount of studies on the tourism industry which places focus on the term 'Environmentally friendly' that embraces the ideas of nurturing the natural resources and environment. In a more exact term, the definition of environmentally friendly tourism is defined by the support given to the preservation areas and natural resources in reducing the negative impacts of the tourism industry. Based on Tavares et al. [29], in the study of the Arco region in Angola, the impacts associated with trekking in large groups and leisure parties were emphasized. This study was applied on the fragile wetland ecosystem in that region and assessed the impact of tourism. The study indicated only positive aspects associated with tourism activities given by the uniqueness of the landscape and the forms of the natural heritage, and the cultural, economical, and environmental conditions which interact with the communities. In contrast to these statements, the higher negative impacts of the tourism activities were associated with sedimentation and erosion as well as the emergence of social conflicts. Therefore, according to literature, there are three major aspects of this term which include wildlife tourism, cultural/heritage tourism and ecotourism [26]. This paper reviews four aspects of knowledge about the wise use of wetlands: local communities' awareness, guiding definitions on the wetland, the wise use of wetland capabilities and environmentally friendly behaviour regarding tourism development in the case of the Gandoman wetlands.

\section{LOCAL COMMUNITIES, MANAGEMENT AND TOURISM DEVELOPMENT}

Tourism resources of a destination are one of the most significant aspects in tourist destinations. Therefore, a tourist destination must establish a good resource administration to manage resource conservation, management and exploitation in a proper order. Local communities who have knowledge with regard to tourism development normally do not wish to have tourism activities negatively affecting their daily lives, but they still believe in the benefits and added income which can be generated through tourism development. Therefore, administrative bodies must preserve a good relationship with the local communities staying in the wetland areas [30]. This view is supported by Dahlberg and Tidsskrift (2005), who undertook an investigation of the complex weave of dependence and conflict in the natural environment and use of local resources by a particular group of local women in South Africa. The result showed multiple interpretations of the environment, and an unexpected high degree of variability in resource use. The study did however find solutions for the problem of the contesting claims to natural resources [31]. Butler (1999) argues, with regard to sustainable tourism, sustainable development (SD), has focused on environmental protection that is considered exclusive in the human context [32]. Although these arguments do not ethically and morally incorporate the human dimension, there are clear implications for the development of the 
prospects and socio-cultural integrity within environmental conservation itself. It has become increasingly realized that conservation is not separated from physical development matters. If the latter is overlooked, sustainability will surely be compromised [33].

\section{STUDY AREA AND ITS CAPABILITIES}

This study covers the area of the Gandoman wetland within the Boroujen district in the province of Chahar-Mahal and Bakhtiari. The province is located in the southwest of Iran, which is near the Zagros Mountains. As mentioned earlier, the Gandoman wetland is located at the latitude of $49^{\circ}-31^{\prime}$ to $53^{\circ}-31^{\prime} \mathrm{N}$ and longitude of $5^{\circ}-51$ to $7^{\circ}-51^{\prime} \mathrm{E}$. This wetland covers 1200 ha of the ChaharMahal and Bakhtiari province of Iran. In average, this wetland has a minimum height of $2219 \mathrm{~m}$ above sea level. Additionally, this wetland is one of the most popular wetlands developed after the Chaghakhor wetland within this province. There is no exact average number of freezing days in Gandoman. In the Boroujen station, where there are both cold and warm seasons, with transient seasonal months that vary from warm to cold and cold to warm. The transient seasonal months in the Boroujen station during the cold season are January, February, March and April with 129 freezing days; whereas the warm season is from July to September. This condition is indicated by the cold rush of air caused by the polarization of the Siberian high-pressure centre (see Fig. 2) [7].

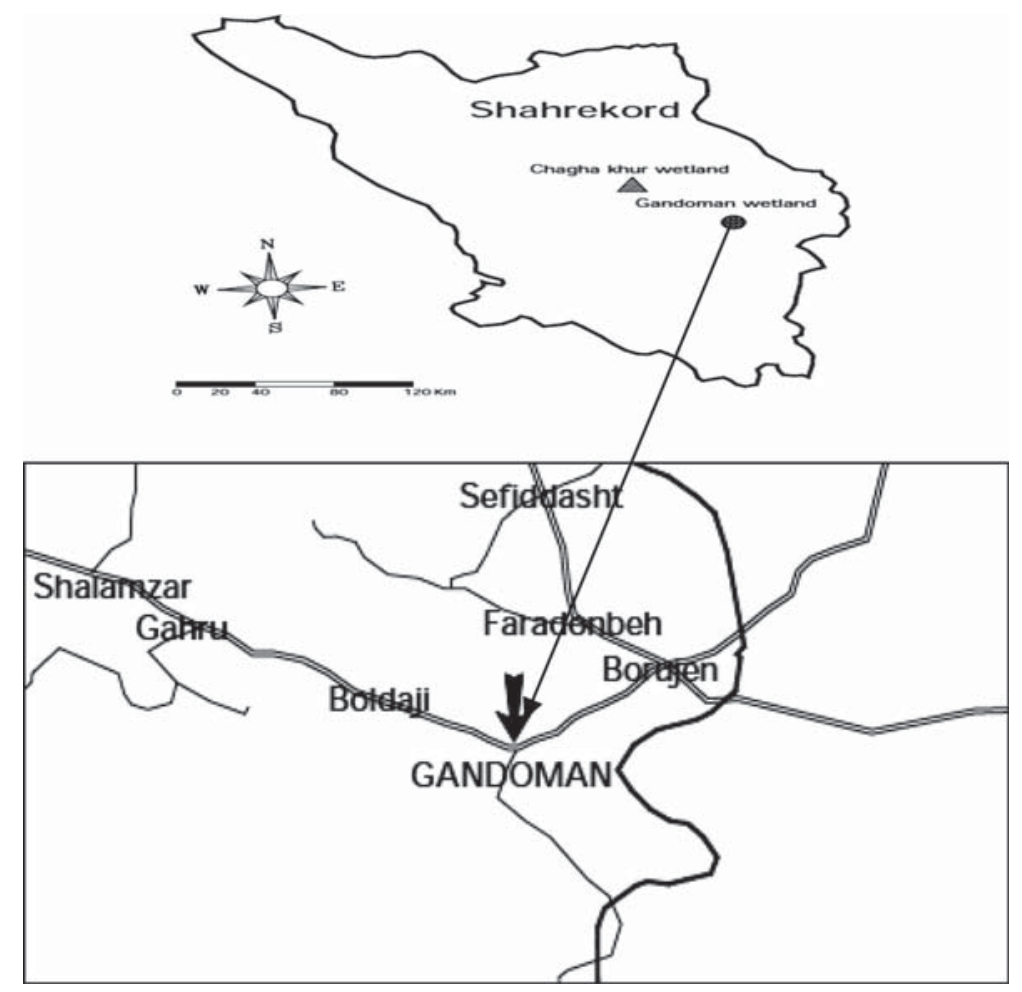

Figure 2: Location of the study area in Chahar-Mahal and Bakhtiari province. 
This wetland has different capabilities as described in the following attributes:

1. Gandoman plants:

This wetland has four major groups of plants which include 1. Polygonummite schromk, 2. Butumus umbellatus, 3. Trapa natans, and 4. Najas Marina (see Photo 1).

According to the field study of this wetland, in 2008, various areas in the wetland had been drained and people who were living in the surrounding area had been forced to make a road through the wetland for the purpose of transportation. In addition to this, tourists, hunters and farmers are the other 'participants' for whatever incidences that had occurred in this wetland, such as open burning within the vicinity of this wetland.

2. Gandoman wildlife:

According to 2007 report from the Ministry of the Environment, there are many types of birds and fauna in Chahar-Mahal and Bakhtiari wetlands that include birds' migration such as Anas crecca, Anas strepera, Tadorna tadorna, Tadorna ferruginea and fish migration such as Afanoos, Ladi Coolia, Gamboozia and others (see Photos $2 \& 3$ ).

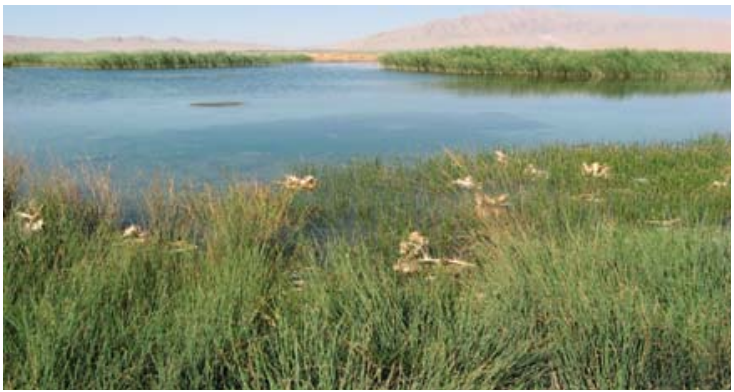

Photo 1: Landscape of the Gandoman plants.

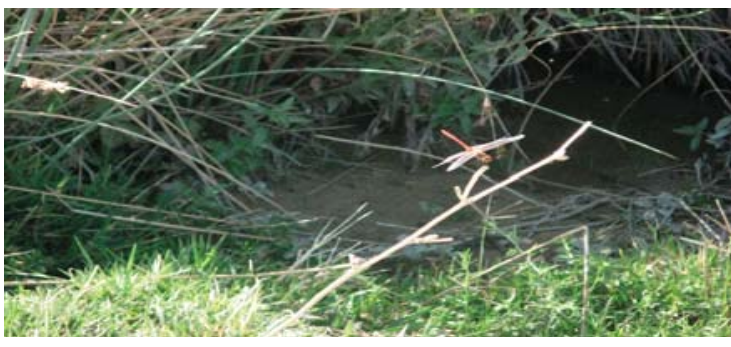

Photo 2: View of Fauna in Gandoman wetland.

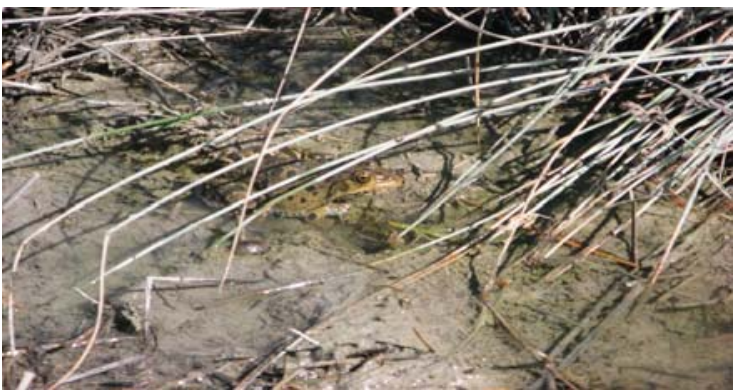

Photo 3: View of Fauna in Gandoman wetland. 


\subsection{Tourism population in the Gandoman district}

According to statistics from the previous decades, the population of the province in 1996 was 761,168 . Subsequently, over the next years, in 2000 , the population of this province amounted to 821,975 ; while on the other hand, the average of growth during this year was $65-75 \%$ (Statistical organization, 2000). The last statistical report was released in 2005 , where the population in this province was 857,910 , a figure which was related to seasonal migration [34], while the population in the Gandoman district was recorded to have been 5,847 (see Table 1) [35].

\subsection{The wetland landscape}

The Gandoman wetland boasts of 980 ha and a stretch of water approximately 2,219 $\mathrm{m}$ long. During the field study conducted in June 2008, after observing that a large space of the wetland was drained, it was realized that the wetland tourism was under threat. This wetland has a lot of potential where different facilities for both entertainment and recreation can be provided to visitors. Besides this, around this wetland area, there are many horses riding clubs that have been established for training and breeding horses. One of the oldest traditional culture originating from years ago is horse riding. This sport is particularly popular with the Bakhtiari tribe, who are a combination of native and Arabic tribes. Tourists in this district often come to the wetland with this intention and therefore, horse riding can become one of the main reasons for developing sustainable wetland tourism in the Gandoman wetland.

\section{METHODOLOGY}

In this study, the SWOT analysis has been applied to analyse the capabilities of the wetlands in the Gandoman district in Iran by gleaning through related previous studies. SWOT analysis was primarily selected for this study as "the SWOT analysis tool is great for developing an understanding of an organization or situation and decision making for all sorts of situations in business, organizations and for individuals; and SWOT analysis headings provide a good framework for reviewing strategy,

Table 1: Population in the Gandoman district.

\begin{tabular}{lllll}
\hline District & Space & Population & Rural Divisions & Space \\
\hline Gandoman & 880.79 & 5847 & Gandoman & 231.81 \\
& & & Doraman & 643.69 \\
\hline
\end{tabular}

Source: Chahar-Mahal Province Organization, 2012 [35].

Table 2: SWOT Matrix and determination of strategies.

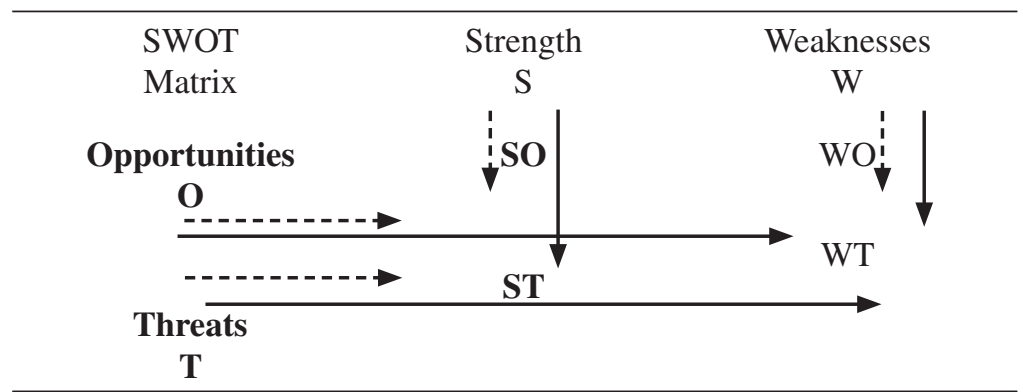

Determination of short term and long term development. Source: [37]. 
position and direction of a company, product, project or person (career)' (see Table 2) [36]. This process seeks to explore and discuss the primary drivers and influences that shape the local communities surrounding the wetlands as well as the wetland tourism development in Gandoman. The main research problem to be identified through the SWOT analysis is to what extent the knowledge and training of the local communities in the Gandoman wetland areas are limited in terms of utilizing these natural resources? On top of that, a series of semi-structured interviews in which a set of pre-determined questions were asked, permitting comparisons to be done based on the response of respondents through SWOT analysis.

Descriptive research takes into account the description of the research and its relations with the earlier incidents in describing the interaction between different states/phases and also current events and conditions [38]. Questions that were covered in this study were the types of tourism impacts in the region towards local communities and local governments, and the effects on training the communities to use wetland potentialities and its relationship with environmentally-friendly behaviour. A sample of 35 stakeholders was selected by systematic random sampling of local communities in Gandoman. Interviews with the official governments and communities, lasting from 30 to 45 min were completed over three weeks, and the SWOT analysis undertaken was based on the field survey carried out from the first of July 2008. Since the aim of the paper is to make use the measurement and field study methods in highlighting the determination of the strengths, (S), weaknesses (W), opportunities $(\mathrm{O})$ and threats $(\mathrm{T})$ of wetland tourism in Gandoman. Based on the internal and external factors of the SWOT analysis, the wetland tourism development based on the environmental capabilities of the Gandoman wetland area has been extracted and identified through the analysis.

\section{RESULTS AND DISCUSSION}

According to previous studies, the most significant wetland capabilities, vulnerabilities and threats are summarized by the SWOT technique. In light of the significant role the wetland tourism industry plays in the Gandoman wetland area, its emphasis on the development of the industry is clearly indicated. The broad thrust of the strategies concerning internal and external factors can be summarized as follows (see Tables 3 and 4).

As aforementioned, these four major strategies are relevant to the circumstances of the Gandoman wetland. In line with the observations of this study, these include:

1. Competitive strategy: strengths and opportunities which are pointed out by the creation of practical solutions $(\mathrm{SO})$.

2. Diversification strategy: proposes the use of inherent strengths to remove threats (ST).

3. Invasive strategy: proposes to remove weaknesses and to use opportunities (WO).

4. Defensive strategy: proposes to remove internal weaknesses and to avoid threats (WT) (see Table 5) [40].

These findings were obtained through descriptive analysis conducted via SWOT analysis for wetland tourism in the Gandoman wetlands. As mentioned in the table above, many insights based on reviews of environment and wetland studies and the broader effort of environmentally-friendly tourism development with regards to training local communities in making use of the various capabilities of the wetland areas have been put forth. Subsequently, in order to develop the wetland tourism industry in Gandoman, opinions of the interviewees such as local community representatives, managers and experts should be considered, where they believe that for effective utilization and implementation, the quality of the tourism impacts on this wetland and sustainable tourism development surrounding this 
Table 3: Internal factors relevant to Gandoman wetland tourism.

Internal Factors

\section{Strengths}

S1. The nature of Gandoman wetland tourism products

S2. Gandoman has natural attractive features

S3. Ability to attract horse breeding and rearing

S4. Unique ecosystem appeals to cold season based activities (rock climbing, ice climbing, skiing, hiking, etc.)

S5. Dominant species of unique wetland birds in Gandoman

S6. Inbound tourists seeking to find convenient accommodation

S7. Strong government management to revive the wetland and eco-tourism in the area

S8. Wetland area activities such as fishing, canoeing and boating based on the available natural resources

S9. The environmentally-friendly tourism is defined by the support given to the preservation areas and natural resources

\section{Weaknesses}

W1. Low standard accommodation

W2. Unlicensed hotels

W3. Lack of empowerment in tourism industry

W4. Lack of government investment in the Gandoman wetland

W5. Imperfection in planning and management

W6. Lack of tourism facilities and infrastructure

W7. Lack of advantages for tourists activities in the area

W8. Lack of local communities' knowledge within the vicinity of the wetland

W9. Existence of some limitations in planning and management guidelines to ensure the development of ecotourism

W10. Lack of information regarding the wise use of the wetland areas

Table 4: External factors relevant to Gandoman wetland tourism.

\section{External Factors}

\section{Opportunities}

O1. New handicrafts markets/products

O2. Ecotourism

O3. Traditional carpet market sector

O4. Musical instruments common in the Bakhtiari tribe

O5. Agriculture, livestock, horses, traditional Bakhtiari rug weaving as job opportunities

O6. 'Bazaar' as a type of famous ancient monuments

O7. Unique climate change of the Siberian high pressure centre

O8. Wise use knowledge in implementing sustainable development

O9. Residents' training and improving the knowledge of the local community

O10. Wise use with increasing responsibility and support of the wetlands

O11. Focus on ensuring the stability, sustainability and accessibility of the wetlands' ecosystems

(Continued) 
Table 4: (Continued)

\section{External Factors}

\section{Threats}

T1. The indiscriminate use of wetland tourism in the Gandoman region

T2. The existing natural pressure on the wetland

T3. Water harvesting for agricultural uses while the wetland needs water

T4. Water pollution due to agricultural waste

T5. Peat picked to be used in mushroom cultivation as well as fires that caused by the dairy farmers or hunters

T6. Environmental degradation surrounding the wetland

T7. The negative impacts of the tourism industry

Source: Field Survey, 2008: [39].

Table 5: SWOT matrix and derivation of key strategies in the wetland tourism capabilities in the Gandoman wetland.

\section{Competitive: (SO) Invasive: (WO)}

Enact new handicrafts markets/products based Provide adequate and high quality accommodaon wetlands tourism $(\mathrm{S} 1, \mathrm{O} 1)$. tion services for the development of ecotourism Increase conservation circumstances for natural (W1, O2).

attractions to develop ecotourism (S2, O2). Increasing government investment to improve Provide information to increase local awareness planning and management with regard to wise regarding traditional Bazaars as famous ancient use knowledge in creating sustainable developmonuments for wetland tourism (S1, O6). ment (W5, O8).

Place more emphasis on the wise use of the Review ecotourism planning and management wetland and the knowledge of the Gandoman guidelines to attract more tourists to wetland wetland as a means of unique ecosystem tourism in Gandoman (W5, W9, O2). $(\mathrm{S} 4, \mathrm{O} 8)$.

Developers should consider the abilities of the horse breeding and rearing in local tourist destinations nearby the Gandoman wetland (S3, O5).

Enactment of strong government management to focus on sustainability and accessibility of the wetland ecosystems (S7, O11). Increasing supervision on dominant and unique species to protect the wetland birds to enable bird-watching as a major attraction in ecotourism (S5, O2).

Using the experiences of the traditional market sector with Bakhtiari carpet weaving as an attractive feature $(\mathrm{S} 2, \mathrm{O} 3)$.
Activities should be synchronized with local communities to allow eco-tourists to assist tourists in cold seasons especially during the unique climate change coming from the Siberian high pressure centre (W8, O7).

Eradicating unlicensed hotels while establishing traditional hotels with national or international licenses to develop the traditional market sector (W2, O2, O3).

Using the potential of ecotourism to remove lack of empowerment (W3, O2).

Enacting and supervising observations on planning and management to remove the shortcomings in wise use knowledge to enhance sustainable development (W5, O8).

(Continued) 
Table 5: (Continued)

Competitive: (SO) Invasive: (WO)

Providing information for residents' training and the improvement of their knowledge by governmental management in the wise use of wetlands (S7, O9).

Wise use of wetland to increase and support local communities in environmentally-friendly tourism (S9, O10).

Unique climate change of the Siberian high pressure centre which exists in Gandoman will enable make various activities such as fishing, canoeing and boating (S8, O7).
Providing a master plan for residents' training and improving their knowledge for responsible tourism and its support of the wetland (W10, O9, O10). Revising the limitation of the tourism facilities and infrastructures while focusing on the stability, sustainability and accessibility near the wetland areas (W6, O11).

Improving local communities' knowledge in the vicinity of the wetland to enable wise use knowledge (W8, O8).

Remove disadvantages of tourist activities by replacing them with job opportunities through sectors and activities such as agriculture, livestock, horses and traditional rug weaving (W7, O5).

Diversification: (ST)
Introduction to the unique character and
value of the wetlands ecosystem to reduce the
indiscriminate impacts of tourism (S4, T2).
Create job opportunities by traditional carpet
weaving, agriculture, livestock, horse rearing
and wetland tourism to increase economic
growth and demand for all regional natural
attractions $(\mathrm{S} 2, \mathrm{~T} 3)$.

The exact area affected and impacted by water pollution should be studied by the government to act on reducing the negative impact of pollution from agricultural waste (S7, T4). Focus on the environmental degradation surrounding the wetlands which have dominant and unique species of wetland birds as an attraction for bird watching (S5, T6).

Environmental supervision to prevent negative impacts of tourism towards nature from Gandoman wetland related tourism products (T7, S1). Limiting the peat picked to be used in mushroom cultivation and inhibiting fires caused by the dairy farmers or hunters through strong governmental management in reviving the wetland tourism in this area (T5, S7). Applying the patterns of environmentally-friendly tourism to support and preserve natural resources in reducing indiscriminate exploitation of the wetland tourism in the Gandoman region (S8, T1).

\section{Defensive: (WT)}

The use of standardized accommodation and establishing licensed hotels in preventing the existing natural pressure on the wetland (W1, W2, T2).

Introduction of a proposed format for wetlands tourism projects to help avoid unplanned growth of economic and conservation activities (W1, T7).

Initiation of a master plan by the government to prevent water harvesting for agricultural uses and to prevent water pollution (W5, T3, T4).

Consistent use of information regarding the wise use of the wetlands with planning and management guidelines to ensure ecotourism and environmentally appropriate technologies in reducing negative impacts in the region ( W9, T7). Preparing strategies in empowering enforcement and reducing environmental degradation from the tourism industry (W3, T6).

Preparing long-term monitoring plans in enhancing local communities' knowledge through government investment in wetland tourism in the Gandoman region (W8, W4, T1). Issuing ecotourism regulations to prevent abuse of the wetland by mushroom cultivation or fires caused by dairy farmers or hunters (W7, T5). 
wetland must be ensured. This study supports these statements where it was discovered that if managers and planners in various relevant organizations seriously work together in activating well-strategized agenda, benefit from wetland tourism in this area can be achieved and derived.

\section{CONCLUSIONS AND RECOMMENDATIONS}

This study aimed to categorize the wetlands tourism development potentialities of the Gandoman wetlands. It should be noted that although natural resources conservation surrounding the study area are undertaken by the Department of the Environment, additional negative conditions such as soil erosion, jungle destruction and decrease of pastures can play key negative roles in the outcome. The region's natural environments and diverse cultural heritage are major tourism attractions. Opportunities and threats in the study area in terms of sustainable tourism development were identified through SWOT analysis. A proper and desirable sustainable tourism development in the area requires more government cooperation and effective organization in different levels of management to enable a positive relationship between tourism industry and local communities. Environmentally-friendly tourism development can be achieved by training local communities to make use of the various capabilities found in wetland areas, particularly in the study area.

Excessive or poorly managed tourism development can threaten the physical integrity and significantly disturb the characteristics of nature. Thus, managers and planners in various organizations can work together in organizing an agenda for the benefit of wetland tourism development and its sustainability. It is recommended that further studies be conducted on this subject matter, particularly in aspects such as encouragement of the public and private sectors' investment in the tourism industry; active participation of local communities in the vicinity of wetlands areas in this province; utilizing their knowledge with regard to heritage, culture and traditional beliefs; support of protected areas such as wetlands through wise utilization of wetlands tourism and ecotourism; use of motor boats for training tour operators in the surrounding wetland areas; and finally, development of a master plan for local communities and their participation to reduce potential negative impacts of wetlands tourism.

\section{REFERENCES}

[1] Urry, J., The tourist gaze 'revisited'. American Behavioral Scientist, 36(2), pp. 172-186, 1992. doi: http://dx.doi.org/10.1177/0002764292036002005

[2] Alaeddinoglu, F. \& Can, A.S., Identification and classification of nature-based tourism resources: Western Lake Van basin, Turkey. Procedia-Social and Behavioral Sciences, 19, pp. 198-207, 2011. doi: http://dx.doi.org/10.1016/j.sbspro.2011.05.124

[3] Hearne, R.R. \& Salinas, Z.M., The use of choice experiments in the analysis of tourist preferences for ecotourism development in Costa Rica. Journal of Environmental Management, 65(2), pp. 153-163, 2002. doi: http://dx.doi.org/10.1006/jema.2001.0541

[4] Shrestha, U., Comunity participation in wetland conservation in Nepal. The Journal of Agriculture and Environment, 12, pp. 140-147, 2011.

[5] http://www.dpiw.tas.gov.au/inter.nsf/WebPages/RPIO4YS94B?open, Wise Use of Wetlands (accessed 16 November 2012).

[6] Zhang, L., Wang, M.H., Hu, J. \& Ho, Y.-S., A review of published wetland research, 1991-2008: Ecological engineering and ecosystem restoration. Ecological Engineering, 36, pp. 973-980, 2010. doi: http://dx.doi.org/10.1016/j.ecoleng.2010.04.029

[7] http://Iran.farsfoundation.net/en/iran-knowing/tourism-iniran/iranian-tourist-attractions/667chahar-mahaal10/5829 gandoman-wetland.html. 
[8] Sandwith, T., Nature-based Tourism: A Key Strategy for Sustaining Biodiversity in KwaZuluNatal, South Africa, City, 1999.

[9] Andriotis, K. \& Vaughan, R.D., Urban residents' attitudes toward tourism development: the case of Crete. Journal of Travel Research, 42, pp. 172-185, 2003. doi: http://dx.doi. org $/ 10.1177 / 0047287503257488$

[10] Williams, S., McCartney, M. \& Williams, S., Water Policy Briefing Series, Sumith Fernando: City, 2006.

[11] Lim, C. \& McAleer, M., Use of Wetlands for Sustainable Tourism Management, City, 2002.

[12] Wernerfelt, B., A resource-based view of the firm. Strategic Management Journal, 5(2), pp. 171-180, 2006.doi: http://dx.doi.org/10.1002/smj.4250050207

[13] Barney, J., Firm resources and sustained competitive advantage. Journal of Management, 17(1), pp. 99-120, 1991. doi: http://dx.doi.org/10.1177/014920639101700108

[14] Barney, J.B., The resource-based theory of the firm. Organization Science, 7(5), p. 469, 1996. doi: http://dx.doi.org/10.1287/orsc.7.5.469

[15] Foss, N.J., Resources, Firms, and Strategies: A Reader in the Resource-based Perspective, Oxford University Press: USA, 1998.

[16] Eisenhardt, K.M. \& Martin, J.A., Dynamic capabilities: what are they? Strategic Management Journal, 21, pp. 1105-1121, 2000. doi: http://dx.doi.org/10.1002/10970266(200010/11)21:10/11<1105::AID-SMJ133>3.0.CO;2-E

[17] Teece, D.J., Explicating Dynamic Capabilities: Asset Selection, Coordination, and Entrepreneurship in Strategic Management Theory, City, 2003.

[18] Blain, C., Levy, S.E. \& Ritchie, J.R.B., Destination branding: insights and practices from destination management organizations. Journal of Travel Research, 43(4), pp. 328-338, 2005. doi: http://dx.doi.org/10.1177/0047287505274646

[19] Hosany, S., Ekinci, Y. \& Uysal, M., Destination image and destination personality: an application of branding theories to tourism places. Journal of Business Research, 59(5), pp. 638-642, 2006.doi: http://dx.doi.org/10.1016/j.jbusres.2006.01.001

[20] Melian-Gonzalez, A. \& García-Falcón, J.M., Competitive potential of tourism in destinations. Annals of Tourism Research, 30(3), pp. 720-740, 2003. doi: http://dx.doi.org/10.1016/S01607383(03)00047-1

[21] Rodríguez-Díaz, M. \& Espino-Rodríguez, T.F., A model of strategic evaluation of a tourism destination based on internal and relational capabilities. Journal of Travel Research, 46(4), pp. 368-380, 2008. doi: http://dx.doi.org/10.1177/0047287507308324

[22] Haugland, S.A., Ness, H., Grønseth, B.O. \& Aarstad, J., Development of tourism destinations: an integrated multilevel perspective. Annals of Tourism Research, 38(1), pp. 268-290, 2011. doi: http://dx.doi.org/10.1016/j.annals.2010.08.008

[23] Turner, R.K., Van Den Bergh, J.C.J.M., Söderqvist, T., Barendregt, A., van der Straaten, J., Maltby, E. \& van Ierland, E.C., Ecological-economic analysis of wetlands: Scientific integration for management and policy. Ecological Economics, 35(1), pp. 7-23, 2000. doi: http:// dx.doi.org/10.1016/S0921-8009(00)00164-6

[24] Dugan, P., Wetlands in Danger: A World Conservation Atlas, Oxford University Press, 1993.

[25] Williams, M., The human use of wetlands. Progress in Human Geography, 15(1), pp. 1-22, 1991. doi: http://dx.doi.org/10.1177/030913259101500101

[26] UNESCO, Towards Environmentally Friendly Tourism in Arabian Biosphere Reserves: Case Study:Al Reem, Qatar, UNESCO: Doha, 2008. 
[27] Khoshkam, M. \& Marzuki, A., Environmentally friendly wetlands management for tourism. WIT Press, pp. 563-572, 2011. www.witpress.com, ISSN 1743-3541 (on-line) WIT Transactions on Ecology and The Environment, Vol 148, (C 2011 WIT Press doi:10.2495/RAV110511. doi: http://dx.doi.org/10.2495/RAV110511

[28] Sah, J.P. \& Heinen, J.T., Wetland resource use and conservation attitudes among indigenous and migrant peoples in Ghodaghodi Lake area, Nepal. Environmental Conservation, 28(4), pp. 345-356, 2001. doi: http://dx.doi.org/10.1017/S0376892901000376

[29] Tavares, A., Máquina, M. \& Henriques, M., The impact of tourism in a fragile wetland ecosystem in Angola: the Arco (Namibe) case study. Sustainable Tourism V, p. 205, 2012.

[30] Tsaur, S.H., Lin, Y.C. \& Lin, J.H., Evaluating ecotourism sustainability from the integrated perspective of resource, community and tourism. Tourism Management, 27(4), pp. 640-653, 2006. doi: http://dx.doi.org/10.1016/j.tourman.2005.02.006

[31] Dahlberg, A., Local resource use, nature conservation and tourism in Mkuze wetlands, South Africa: a complex weave of dependence and conflict. Geografisk Tidsskrift, 105(1), p. 43, 2005. doi: http://dx.doi.org/10.1080/00167223.2005.10649525

[32] Butler, R.W., Sustainable tourism: a state of the art review. Tourism Geographies, 1(1), pp. 7-25, 1999.doi: http://dx.doi.org/10.1080/14616689908721291

[33] Cater, E.A., Tourism in the Yunnan great rivers national parks system project: prospects for sustainability. Tourism Geographies, 2(4), pp. 472-489, 2000. doi: http://dx.doi. org/10.1080/146166800750035549

[34] http://www.amar.org.ir/Default.aspx?tabid=115\&agentType=View\&PropertyID=850 (accessed 30 March 2012).

[35] http://www.ostanchb.ir/ShowPage.aspx?page_=form\&order=show\&lang=1\&sub=3\&PageId= $683 \&$ codeV=1\&tempname=broujen (accessed 16 August 2006).

[36] Popa, V.N., Romanian Universities SWOT Analysis, World Scientific and Engineering Academy and Society (WSEAS): City, 2010.

[37] Fazel Nia, G. \& Hedayati, S., Suitable strategies for tourism development Case study: Zarivar Lake. Journal of Geography and Development, 19, pp. 154-170, 2010.

[38] Kaptan, S., Scientific research and statistical techniques. Tekışık Ofset, Ankara, 1998.

[39] The Environmentalists Society of Boroujen city (NGO), Gandoman Wetland, http://www .tabiatepak.blogfa.com/post-10.aspx (accessed 16 April 2012).

[40] Nouri, J., Karbassi, A. \& Mirkia, S., Environmental management of coastal regions in the Caspian Sea. International Journal of Environmental Science and Technology, 5(1), pp. 43-52, 2008.doi: http://dx.doi.org/10.1007/BF03325996 